\title{
Do Long-Term Continuous Cropping and Pesticides Affect Earthworm Communities?
}

\author{
Kinga Treder*, Magdalena Jastrzębska ${ }^{\circledR}$, Marta Katarzyna Kostrzewska \\ and Przemysław Makowski
}

Department of Agroecosystems, Faculty of Environmental Management and Agriculture, University of Warmia and Mazury in Olsztyn, Plac Łódzki 3, 10-718 Olsztyn, Poland; magdalena.jastrzebska@uwm.edu.pl (M.J.); marta.kostrzewska@uwm.edu.pl (M.K.K.); przemyslaw.makowski@uwm.edu.pl (P.M.)

* Correspondence: kinga.treder@uwm.edu.pl

Received: 4 March 2020; Accepted: 16 April 2020; Published: 20 April 2020

\begin{abstract}
Earthworm species composition, the density of individuals, and their biomass were investigated in spring barley and faba bean fields in a long-term (52-year) experiment conducted at the Production and Experimental Station in Bałcyny, in north-eastern Poland ( $\left.53^{\circ} 40^{\prime} \mathrm{N} ; 19^{\circ} 50^{\prime} \mathrm{E}\right)$. Additionally, post-harvest residues biomass, soil organic matter (SOM), and soil $\mathrm{pH}$ were recorded. The above traits were investigated using two experimental factors: I. cropping system-continuous cropping (CC) vs. crop rotation (CR) and II. pesticide plant protection: herbicide + fungicide $(\mathrm{HF}+)$ vs. no plant protection (HF-). A total of three species of Lumbricidae were found: Aporrectodea caliginosa (Sav.) in both crops, Aporrectodea rosea (Sav.) in spring barley, and Lumbricus terrestris (L.) in faba bean. The density and biomass of earthworms were unaffected by experimental treatments in spring barley fields, whereas in faba bean CC increased and HF+ decreased earthworm density and biomass in comparison with $\mathrm{CR}$ and HF- respectively. Total post-harvest residues in faba bean fields were higher under CC in relation to $\mathrm{CR}$ and under HF+ compared with HF- treatment in both crops. Compared to $\mathrm{CR}, \mathrm{CC}$ increased soil $\mathrm{pH}$ in spring barley fields and decreased in faba bean fields. Experimental factors did not affect SOM. Earthworm density and biomass were positively correlated with SOM content.
\end{abstract}

Keywords: soil organic matter; soil $\mathrm{pH}$; post-harvest residues; crop rotation; Hordeum vulgare L.; Vicia faba L. ssp. minor

\section{Introduction}

Earthworms are strategic invertebrates in agroecosystems. The drillosphere, composed of horizontal and vertical burrows and casts created by earthworms, significantly affects soil structure and enhances gas exchange, water infiltration, and root penetration across the soil profile [1-4]. Earthworms improve the content of soil organic matter, contribute to humus formation processes and form a mull soil by burrowing large quantities of surface organic matter to belowground and relocating soil from depths to the top by casting. These invertebrates have an impact on the structure, concentration, and activity of soil microbial communities involved in organic matter decomposition and mineralization [5,6]. Earthworms casts are characterized by higher $\mathrm{pH}, \mathrm{C}, \mathrm{Ca}^{2+}, \mathrm{Mg}^{2+}$, and $\mathrm{K}^{+}$ contents than surrounding soil aggregates and incorporate nutrients available for plants $[7,8]$. The $\mathrm{N}$ mineral availability increases with earthworm abundance $[9,10]$. Earthworms, through their interaction with microorganisms, are essential factors influencing soil organic carbon and its dynamics $[10,11]$. In the presence of earthworms, greater production of plant growth regulators was observed [12,13]. The non-negligible role of earthworms on improving plant tolerance to parasitic nematodes and a reduction in the severity of take-all disease was also reported [14-16]. The above-mentioned benefits 
of earthworm activity contribute to plant growth and production as seen by aboveground biomass and crop yield increases [17-19].

Density, diversity, structure, and activity of earthworm populations in agroecosystems are dependent on agricultural management [20]. Intensification of agricultural practices based on multiple tillage treatments, simple crop sequence, minor organic fertilization, and chemical methods of plant protection have a negative effect on earthworm populations. Long-term, intensive, and deep tillage can decline earthworm (mainly anecic) abundance [21-24] whereas shallow plowing with residue mixing and conservation cultivation techniques can increase their number [25-27]. Organic fertilizers such as manure, crop residues, and mulch are the source of food supply for soil biota and have a positive impact on their populations [28,29]. The conclusion from the literature on the effect of pesticides on earthworm populations is still ambiguous. The effect of pesticides on soil organisms is closely related to their active substances and doses. Some of them, especially fungicides and insecticides, are toxic or lethal to earthworms and cause a decrease in cocoon production and density of juveniles, a delay in growth and a mortality increase [3,30-32]. Herbicides were also found to have an adverse impact on earthworms by causing histological changes in their body tissues and increasing mortality [33-37]. However, earthworms can develop adaptation mechanisms against the toxic effect of pesticides [38,39].

The importance of earthworms in agroecosystems is well-recognized, but the long-term effects of continuous cropping and pesticide use on earthworm populations are much less documented. The objective of this study was to examine the impact of the above-mentioned factors on species composition, density, and biomass of earthworms, post-harvest residue biomass, soil organic matter, and soil $\mathrm{pH}$. The alternative hypothesis assumed that long-term continuous cropping and chemical plant protection have an impact on earthworm communities was tested against the null hypothesis that the above factors do not affect the analyzed parameters.

\section{Materials and Methods}

\subsection{Experimental Design and Crop Management}

The field experiment was initiated in autumn 1967 in the Production and Experimental Station in Bałcyny in north-eastern Poland $\left(53^{\circ} 40^{\prime} \mathrm{N} ; 19^{\circ} 50^{\prime} \mathrm{E}\right)$. During the first five years, nine crops were sown in a continuous cropping system (growing of the same crop on the same field each year). In 1972, two crop rotations were included to analyze continuous cropping impact. Crop rotation varied throughout the experiment. Currently, twelve crops in continuous cropping and in two crop rotations (growing different crops one after the other on the same field) are being sown. The crop rotations are A. sugar beet, maize, spring barley, peas, winter rape, and winter wheat; B. potato, oats, fiber flax, winter rye, faba bean, and winter triticale.

Fertilization in the first sixteen years was the only mineral. Since 1983 farmyard manure was included in doses: $30 \mathrm{tha}^{-1}$ on potato/sugar beet field and $15 \mathrm{tha}^{-1}$ every three years in a continuous cropping system. Mineral fertilizers are applied in terms and doses respective to each crop's needs.

In one part of every crop field, no pesticides have been ever applied, which provides a unique chance to study no plant protection effect after 52-years of a continuous cropping and crop rotation system. To have a comparison for these results on the other parts of each crop field, herbicides (since 1972 till now) and fungicides (since 1983 till now) have been included. Throughout the experiment, the use of pesticides has been updated according to The Institute of Plant Protection National Research Institute recommendations.

The results presented in this paper were based on two crops differing in their biology and agricultural importance: spring barley (cultivar Radek) and faba bean (cultivar Amigo). Spring barley is grass with a short root system and short vegetation period whereas faba bean has a deep, well-developed root system with nitrogen-fixing nodules. Faba bean, by nitrogen fixation and high mass of residues, increases soil biological activity, organic matter content, porosity and soil moisture, which has an impact on earthworm communities [40]. 
Basic agricultural data for spring barley and faba bean in 2019 are presented in Table 1.

Table 1. Basic agricultural data for spring barley and faba bean in 2019.

\begin{tabular}{ccc}
\hline Item & Spring Barley & Faba Bean \\
\hline Soil tillage system & Plow tillage (with crop residues incorporation after harvest) \\
\hline Mineral fertilisation & $70^{1}$ & $60^{1}$ \\
$-\mathrm{P}_{2} \mathrm{O}_{5}(\mathrm{~kg} / \mathrm{ha})$ & $100^{1}$ & $100^{1}$ \\
$-\mathrm{K}_{2} \mathrm{O}(\mathrm{kg} / \mathrm{ha})$ & $70\left(50^{1}+20^{2}\right)$ & $40^{1}$ \\
$-\mathrm{N}(\mathrm{kg} / \mathrm{ha})$ &
\end{tabular}

Plant protection

herbicides

Mustang 306 SE; florasulam + 2,4-D EHE; 0.5 1/ha; stem elongation *

fungicides

\section{Corum 502.4 SL; bentazon + imazamox; $1.25 \mathrm{l} / \mathrm{ha} ; 16$ leaf unfolded \\ Dash HC; fatty acid esters + alkoxylated alcohols-phosphate esters; $0.6 \mathrm{l} / \mathrm{ha}$; 16 leaf unfolded}

Dithane NeoTec 75 WG; mancozeb; 2.0 $\mathrm{kg} / \mathrm{ha}$; flower buds visible outside leaves

$$
\begin{gathered}
\text { Capalo } 337.5 \mathrm{SE} \text {; fenpropimorph }+ \\
\text { epoxiconazole + metrafenone; } 1.5 \mathrm{l} / \mathrm{ha} \text {; } \\
\text { stem elongation } \\
\text { Amistar } 250 \text { SC; azoxystrobin; } 0.6 \text { l/ha; } \\
\text { flowering } \\
\text { Artea } 330 \text { EC; propiconazole + } \\
\text { cyproconazole; } 0.4 \text { l/ha; flowering }
\end{gathered}
$$

${ }^{1}$-before sowing, ${ }^{2}$-at stem elongation stage; ${ }^{*}$ trade name; active ingredient; rate; crop growth stage.

Two experimental factors were investigated, each with two levels: I. cropping system: continuous cropping (CC) vs. crop rotation (CR), II. plant protection: herbicide + fungicide (HF+) vs. no plant protection (HF-). In both spring barley and faba bean, particular experimental treatments (CC-HF+, CC-HF-, CR-HF+, CR-HF-) were performed in 3 replications (i.e., plots). From each plot 3 samples were taken. That brought the total to 9 samples for each treatment. Each plot size was $27 \mathrm{~m}^{2}$.

\subsection{Soil Characteristics}

The experiment was established on Luvisol medium soil, derived from light loam lying on loamy sand. At the beginning of the lasting rotation (2016) soil contained an average ( $\mathrm{mg} \mathrm{kg}^{-1}$ ) of available forms of phosphorous-289.3, potassium-258.5, magnesium-55.0, total nitrogen-800 with $1.1 \%$ $\mathrm{C}_{\mathrm{org}}$, and $\mathrm{pH}-5.7$.

\subsection{Meteorological Data}

The climate in this region is temperate humid, with annual total precipitation around $587.5 \mathrm{~mm}$ and a mean annual air temperature of $7.9^{\circ} \mathrm{C}$ (data for the years 1981-2015). Weather conditions of the July-September 2019 period are presented in Figure 1. High air temperature in combination with small rainfall before sampling in August could have reduced earthworm activity and biomass. In September, the rainfall and temperature were more favorable for earthworms [41]. 


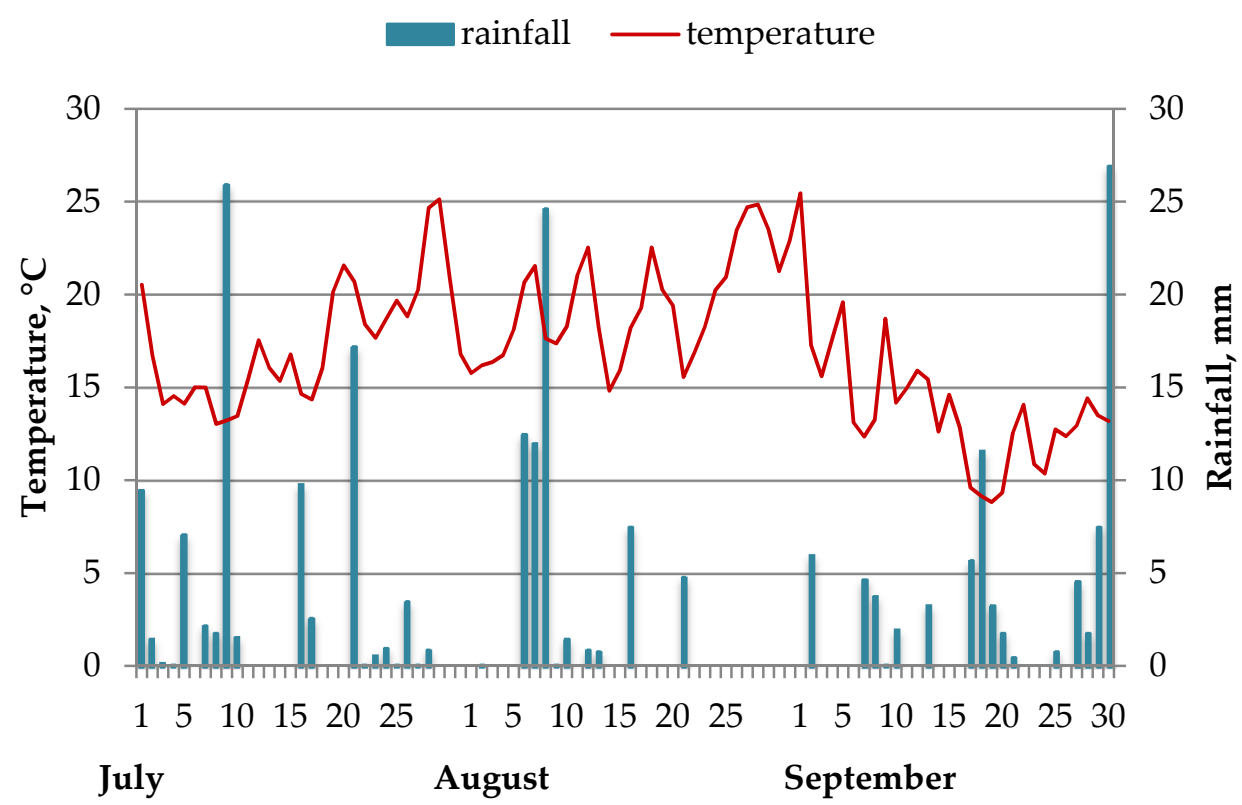

Figure 1. Daily temperature and rainfall before sampling.

\subsection{Sampling}

\subsubsection{Post-Harvest Residue Sampling and Preparation}

Just after harvest, the post-harvest residues (crop and weed bottom stalks with roots) were removed from a surface area of $0.40 \mathrm{~m}^{2}$ and a depth of $0.30 \mathrm{~m}$ in three replications from each plot. Residues were transported to the laboratory in plastic bags. Crop and weed residues were separated, washed under tap water and air-dried for several days. Crop residues were split into shoots and roots. The dry mass of post-harvest residues was weighed.

\subsubsection{Soil Sampling and Preparation}

Three soil samples from each plot were selected on the days of earthworm collection. Soil samples were taken in three replications from each plot from a 0-30 cm depth with a hand-held twisting probe (Egner's soil sampler) and returned in plastic bags to the laboratory. Stones and plant residues were removed from the soil. Soil samples were air-dried in plastic trays and then passed through a $2 \mathrm{~mm}$ sieve to prepare homogenous samples.

\section{Soil Organic Matter Analysis}

The soil organic matter (SOM) was determined using the loss-on-ignition method [42]. Soil samples (each of mass $10 \mathrm{~g}$ ) were oven-dried in crucibles at $105^{\circ} \mathrm{C}$ for $2 \mathrm{~h}$ to remove hygroscopic water and then cooled and weighed. Afterward, soil samples were heated at $360^{\circ} \mathrm{C}$ for $2 \mathrm{~h}$ and cooled and weighed. SOM (\%) was calculated as the mass lost during combustion:

$$
\mathrm{SOM}=\left[\left(\text { soil weight } 105^{\circ} \mathrm{C}-\text { soil weight } 360{ }^{\circ} \mathrm{C}\right) / \text { soil weight } 105^{\circ} \mathrm{C}\right] \times 100
$$

\section{Soil pH Determination}

Soil $\mathrm{pH}$ was determined using the potentiometric method after water extraction $\left(\mathrm{pH}\left(\mathrm{H}_{2} \mathrm{O}\right)\right)$. In glass beakers, $10 \mathrm{~g}$ of the air-dried and sieved soil samples were mixed with $25 \mathrm{~mL}$ of distilled water and shaken. After two hours of equilibration, electrical conductance was measured in soil-water suspension for 10 min using a Hanna HI 221 (Hanna Instruments) pH meter. 


\subsubsection{Earthworm Sampling and Identification}

On 12 plots of each crop, three soil samples $(25 \mathrm{~cm} \times 25 \mathrm{~cm} \times 40 \mathrm{~cm}$ depth) were sampled after each crop harvest: spring barley-1.08.2019 and faba bean-26.09.2019. Earthworms were selected from soil blocks by the hand-sorting method. In the laboratory, earthworms were rinsed, dried, weighed (data refers to live biomass), narcotized in 35\% ethyl alcohol and preserved in $4 \%$ formalin and $75 \%$ ethyl alcohol. Clitelated individuals were classified into species level, and juveniles were classified into species or genera level by external morphology using keys [41].

\subsection{Statistical Analysis}

The data were analyzed statistically by a two-factorial analysis of variance ANOVA in the STATISTICA (data analysis software system), version 12, StatSoft. Homogeneous groups were estimated by Duncan's test at a $p<0.05$. The Shapiro-Wilk W-test was used for testing the normality of variable distribution and Levene's test for homogeneity of variance. The correlation coefficients were calculated to measure the strength and direction of the relationship between the variables. The coefficients were determined based on the data from all treatments, separately for spring barley and faba bean.

\section{Results and Discussion}

\subsection{Post-Harvest Residues}

In spring barley fields, the cropping system did not affect the dry mass of post-harvest residue (Table 2). However, CC related to CR increased faba bean mass of shoots, weeds and total residues. Positive influence of CC on faba bean shoots residues biomass was an unexpected result because growing faba bean in the same field year after year leads to the accumulation of autotoxic compounds (mainly phenolic acids) in the soil that inhibits plants growth [43]. In previous studies based on this experiment, Rychcik and Zawiślak [44] reported lower faba density under CC than CR treatment. Though, the lower density of plants may result in their higher biomass. This effect was reported by Kotecki in the experiment with faba bean, were biomass of one plant increased with density decrease [45]. Post-harvest biomass of weeds is the aftereffect of weeds density. The current consensus is that crop rotation, in contrast to continuous cropping, decreases weeds density, which was confirmed by Rychcik in faba bean fields [46].

$\mathrm{HF}+$ compared to HF- treatment resulted in higher production of residues in both crops: in spring barley-shoots, in faba bean-shoots and roots. Furthermore, the biomass of weeds residues was significantly higher in HF- cereal and legume fields in relation to HF+. The presented results are obvious, considering the effects of herbicide use, which was in line with previous studies [46].

In spring barley fields, CC-HF+ increased the total residue biomass in comparison to CC-HF-, while there was no difference between CR-HF+ and CR-HF-. CR-HF- resulted in less spring barley shoots mass production related to CC-HF+ but it was higher than under CC-HF-. The biomass of weed residues under CC-HF- and CR-HF- was higher than in CR-HF+. The achieved results are in agreement with a previous study concerning weed infestation of spring barley in this experiment [47].

Similar results were noted in faba bean fields. The total residue biomass in CC-HF- and CR-HF+ was significantly lower than in CC-HF+ and higher in relation to CR-HF- interaction.

Moreover, HF+ in relation to HF- increased the biomass of faba bean shoots residues in CR, but not as strong as with CC. In relation to other treatments, CC-HF-increased the mass of weed residues. The biomass of faba bean roots was unaffected by treatment interactions. 
Table 2. Dry mass of post-harvest residues $\left(\mathrm{t} \mathrm{ha}^{-1}\right)$.

\begin{tabular}{|c|c|c|c|c|}
\hline Treatments & Total & Shoots & Roots & Weeds \\
\hline \multicolumn{5}{|c|}{ Spring Barley } \\
\hline \multicolumn{5}{|c|}{ cropping system } \\
\hline$C R^{*}$ & $2.82 a^{* *} \pm 0.15$ & $2.07 \mathrm{a} \pm 0.10$ & $0.62 \mathrm{a} \pm 0.07$ & $0.13 a \pm 0.04$ \\
\hline $\mathrm{CC}$ & $2.74 a \pm 0.39$ & $2.04 a \pm 0.33$ & $0.49 a \pm 0.09$ & $0.20 \mathrm{a} \pm 0.03$ \\
\hline \multicolumn{5}{|c|}{ plant protection } \\
\hline HF- & $2.37 \mathrm{~b} \pm 0.21$ & $1.70 b \pm 0.16$ & $0.45 a \pm 0.07$ & $0.23 a \pm 0.02$ \\
\hline $\mathrm{HF}+$ & $3.18 \mathrm{a} \pm 0.26$ & $2.42 \mathrm{a} \pm 0.21$ & $0.66 \mathrm{a} \pm 0.07$ & $0.11 b \pm 0.04$ \\
\hline \multicolumn{5}{|c|}{ interaction } \\
\hline CR-HF- & $2.74 a b \pm 0.27$ & $2.02 b \pm 0.14$ & $0.52 \mathrm{a} \pm 0.10$ & $0.21 \mathrm{a} \pm 0.03$ \\
\hline CR-HF+ & $2.89 a b \pm 0.17$ & $2.12 \mathrm{ab} \pm 0.18$ & $0.71 \mathrm{a} \pm 0.05$ & $0.05 b \pm 0.01$ \\
\hline CC-HF- & $2.00 b \pm 0.16$ & $1.37 \mathrm{c} \pm 0.05$ & $0.38 a \pm 0.11$ & $0.24 a \pm 0.02$ \\
\hline CC-HF+ & $3.48 a \pm 0.46$ & $2.71 \mathrm{a} \pm 0.28$ & $0.61 \mathrm{a} \pm 0.14$ & $0.16 \mathrm{ab} \pm 0.05$ \\
\hline \multicolumn{5}{|c|}{ Faba Bean } \\
\hline \multicolumn{5}{|c|}{ cropping system } \\
\hline CR & $1.24 \mathrm{~b} \pm 0.15$ & $0.42 b \pm 0.09$ & $0.47 a \pm 0.13$ & $0.35 b \pm 0.08$ \\
\hline $\mathrm{CC}$ & $1.93 a \pm 0.18$ & $0.70 \mathrm{a} \pm 0.17$ & $0.49 a \pm 0.14$ & $0.73 a \pm 0.13$ \\
\hline \multicolumn{5}{|c|}{ plant protection } \\
\hline $\mathrm{HF}-$ & $1.29 \mathrm{~b} \pm 0.17$ & $0.29 b \pm 0.05$ & $0.26 b \pm 0.07$ & $0.74 a \pm 0.13$ \\
\hline $\mathrm{HF}+$ & $1.87 \mathrm{a} \pm 0.19$ & $0.82 \mathrm{a} \pm 0.11$ & $0.70 \mathrm{a} \pm 0.10$ & $0.34 b \pm 0.07$ \\
\hline \multicolumn{5}{|c|}{ interaction } \\
\hline CR-HF- & $0.97 \mathrm{c} \pm 0.05$ & $0.25 c \pm 0.07$ & $0.26 a \pm 0.09$ & $0.46 b \pm 0.12$ \\
\hline CR-HF+ & $1.51 \mathrm{~b} \pm 0.18$ & $0.59 b \pm 0.05$ & $0.69 a \pm 0.17$ & $0.23 b \pm 0.06$ \\
\hline CC-HF- & $1.62 b \pm 0.21$ & $0.34 c \pm 0.06$ & $0.27 a \pm 0.13$ & $1.01 \mathrm{a} \pm 0.04$ \\
\hline CC-HF+ & $2.23 a \pm 0.16$ & $1.06 \mathrm{a} \pm 0.09$ & $0.72 \mathrm{a} \pm 0.16$ & $0.45 b \pm 0.12$ \\
\hline
\end{tabular}

* CR-crop rotation, $\mathrm{CC}-$ continuous cropping, $\mathrm{HF}-$-no plant protection, $\mathrm{HF}+$-herbicide + fungicide; ** values with different letters vary significantly (Duncan's test, $p<0.05$ ), $\mathrm{x} \pm$ sem-mean \pm standard error of mean.

\subsection{Soil Organic Matter Content}

Experimental factors and their interactions did not affect the SOM in spring barley and faba bean fields (Table 3). These results are in line with the previous study based on this experiment where the $\mathrm{C}_{\text {org }}$ content in spring barley was comparable to faba bean fields in both cropping systems [48]. The same amounts of manure during every six-year-lasting rotation were applied in all treatments, so this may be the major cause of undifferentiated SOM levels. In contrast to the presented results, some authors [49-51] assert that crop rotation, especially with legumes, gives preferential conditions for soil C increase.

Table 3. Soil organic matter (SOM) (\%).

\begin{tabular}{ccc}
\hline Treatments & Spring Barley & Faba Bean \\
\hline \multicolumn{3}{c}{ cropping system } \\
\hline CR ${ }^{*}$ & $1.86^{* *} \pm 0.10$ & $1.98 \pm 0.04$ \\
CC & $1.88 \pm 0.06$ & $2.08 \pm 0.08$ \\
\hline \multicolumn{3}{c}{ plant protection } \\
\hline HF- & $1.89 \pm 0.11$ \\
HF+ & $1.85 \pm 0.03$ & $1.95 \pm 0.07$ \\
\hline \multicolumn{3}{c}{ interaction } \\
\hline CR-HF- & $1.84 \pm 0.21$ & $2.03 \pm 0.06$ \\
CR-HF+ & $1.87 \pm 0.08$ & $1.93 \pm 0.06$ \\
CC-HF- & $1.93 \pm 0.11$ & $2.20 \pm 0.03$ \\
CC-HF+ & $1.83 \pm 0.03$ & $1.96 \pm 0.13$ \\
\hline
\end{tabular}

* $\mathrm{CR}$-crop rotation, $\mathrm{CC}$ - continuous cropping, $\mathrm{HF}-$-no plant protection, $\mathrm{HF}+$ - herbicide + fungicide; ${ }^{* *}$ values do not differ significantly (Duncan's test, $p<0.05), x \pm$ sem-mean \pm standard error of mean. 


\subsection{Soil $p H$}

In comparison with CR, CC increased soil pH in spring barley (Table 4). Hickman [52] reported lower $\mathrm{pH}$ in maize continuous cropping than in maize-wheat and maize-soybean rotations and soybean continuous cropping. The author suggested that these results may be explained by the long-term use of anhydrous ammonia in maize crops fields. HF+ lowered soil $\mathrm{pH}$ in relation to HF-. Spring barley under HF+ achieved higher yields than HF- (data not published). With higher yields, larger amounts of macroelements were removed from the soil. In spring barley fields, the interaction between cropping system and plant protection was proved. Under CR-HF+ treatment lower soil $\mathrm{pH}$ than under CR-HF- was noted, while there was no difference in soil $\mathrm{pH}$ under CC-HF- and CC-HF+. In faba bean fields, the values of soil $\mathrm{pH}$ were lower in CC than in CR. Dinitrogen-fixing legumes, including faba bean, are considered to generate soil acidification by releasing $\mathrm{H}+$ to rhizosphere [53-55]. Lee [56] reported that continuous legume cultivation increased soil acidity. Comparably, Williams [57] noted soil $\mathrm{pH}$ decrease in a long-term experiment with clover pastures.

Table 4. Soil pH.

\begin{tabular}{ccc}
\hline Treatments & Spring Barley & Faba Bean \\
\hline \multicolumn{3}{c}{ cropping system } \\
\hline $\mathrm{CR}^{*}$ & $6.37 \mathrm{~b} \mathrm{~b}^{* *} \pm 0.11$ & $6.73 \mathrm{a} \pm 0.06$ \\
$\mathrm{CC}$ & $6.89 \mathrm{a} \pm 0.04$ & $6.32 \mathrm{~b} \pm 0.03$ \\
\hline \multicolumn{3}{c}{ plant protection } \\
\hline HF- & $6.74 \mathrm{a} \pm 0.09$ & $6.55 \mathrm{a} \pm 0.09$ \\
$\mathrm{HF}+$ & $6.51 \mathrm{~b} \pm 0.17$ & $6.50 \mathrm{a} \pm 0.12$ \\
\hline \multicolumn{3}{c}{ interaction } \\
\hline CR-HF- & $6.56 \mathrm{~b} \pm 0.06$ & $6.75 \mathrm{a} \pm 0.05$ \\
CR-HF+ & $6.18 \mathrm{c} \pm 0.16$ & $6.72 \mathrm{a} \pm 0.13$ \\
CC-HF- & $6.92 \mathrm{a} \pm 0.06$ & $6.35 \mathrm{~b} \pm 0.03$ \\
CC-HF+ & $6.85 \mathrm{ab} \pm 0.05$ & $6.28 \mathrm{~b} \pm 0.05$ \\
\hline
\end{tabular}

${ }^{*} \mathrm{CR}-$ crop rotation, $\mathrm{CC}$ - continuous cropping, $\mathrm{HF}-$-no plant protection, $\mathrm{HF}+$ - herbicide + fungicide; ${ }^{* *}$ values with different letters vary significantly (Duncan's test, $p<0.05), \mathrm{x} \pm$ sem-mean \pm standard error of mean.

$\mathrm{HF}+$ caused $\mathrm{pH}$ decrease only in spring barley fields. Spring barley under HF+ produced higher yields than under HF- (own data not published). Thus with higher yields, larger amounts of macroelements were removed from the soil.

In faba bean fields, no interaction of cropping system and plant protection on soil $\mathrm{pH}$ was revealed.

\subsection{Earthworm Species Richness and Structure}

In the experimental fields, only three species of Lumbricidae were found: Aporrectodea caliginosa (Sav.), Aporrectodea rosea (Sav.), and Lumbricus terrestris (L.) (Figure 2). The same species composition was reported by Valchovski [58] in cultivated and non-cultivated Vertic Luvisol. The species richness of earthworms in agroecosystems is usually lower than in natural ecosystems and depends mainly on soil type, soil humidity, organic matter content, cultivation treatments, and crop type [59-61]. In both crops, the most numerous species was Aporrectodea caliginosa (Sav.), which occurs commonly in arable lands in all temperate zones [62-64]. This endogenic earthworm can adapt to unfavorable environmental conditions like low soil moisture, low organic matter content, or tillage practices [22,65-67]. Although Aporrectodea rosea (Sav.) is very common in agroecosystems in different crops as well as in pastures $[20,62,68]$, in the current study it was recorded only in spring barley fields under CR-HF+ and CC-HF- treatments. It is worth noting that Lumbricus terrestris (L.) was found only in CR-HF+ and $\mathrm{CC}-\mathrm{HF}+$ faba bean fields. Edwards [62] suggests that one of the limiting factors for Lumbricus terrestris (L.) abundance is soil organic matter. Faba bean plants have a well-developed, extensive fibrous root system, which gives preferential treatment to anecic earthworms. 
In both crops, the majority of the earthworms found were juveniles representing the genera Aporrectodea.

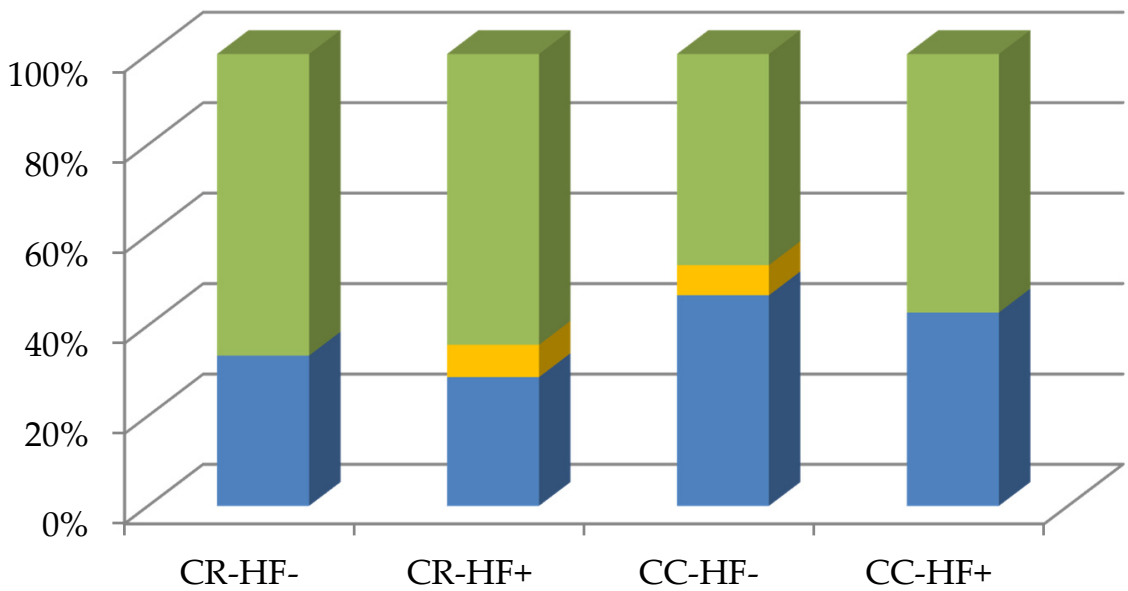

Aporrectodea caliginosa Aporrectodea rosea $\square$ Aporrectodea juveniles

(a)

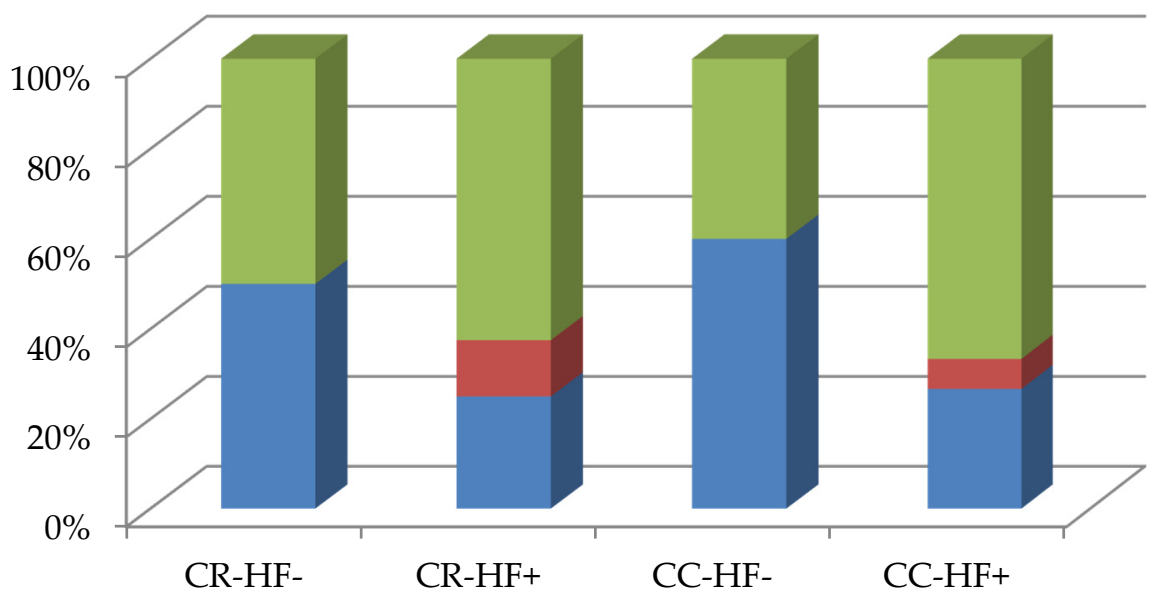

Aporrectodea caliginosa Lumbricus terrestris Aporrectodea juveniles

(b)

Figure 2. Relative abundance (\%) of earthworm species (based on individuals $\mathrm{m}^{-2}$ ) on (a) spring barley and (b) faba bean (B) fields; CR-crop rotation, CC-continuous cropping, HF-- no plant protection, $\mathrm{HF}+$-herbicide + fungicide.

\subsection{Earthworm Density and Biomass}

The density of individuals and biomass of collected earthworms was lower than reported in other works $[64,69,70]$, but comparable with results achieved in other researchers conducted in The Experimental Station in Bałcyny [71-74]. Experimental treatments did not affect the density or biomass of earthworms in spring barley fields (Table 5). Spring crops do not create favorable environmental conditions for earthworm abundance because of low organic matter input and agrotechnical works on fields in early spring when the activity of earthworm communities increases. 
In faba bean fields, both experimental treatments affected earthworm abundance. In comparison with CR, CC increased the density of individuals and biomass of earthworms. The reason for this could be the higher mass of post-harvest residues. In a study by Edwards [62], the abundance of earthworms was two times higher in fields with continuous wheat (for 136 years) than with wheat-root crops. The negative influence of $\mathrm{HF}+$ on the earthworm population in relation to HF- on faba bean fields was apparent in the decrease in individual density and their biomass. Many authors reported a reduction in growth, biomass loss, decreased cocoon production or higher mortality after pesticide application [75-79]. Biomass reduction may be an effect of reduced food intake as a strategy to avoid contamination. Nonetheless, the response to agrochemicals differs depending on earthworm species, the concentration of toxic substances, environmental conditions (soil type, temperature, humidity, organic matter content, etc.) and the duration of exposure [77,80,81]. CC-HF- treatment had a positive influence on earthworm density and biomass in relation to other experimental treatments.

Table 5. Density (individuals $\mathrm{m}^{-2}$ ) and biomass $\left(\mathrm{g} \mathrm{m}^{-2}\right)$ of earthworms in spring barley and faba bean fields.

\begin{tabular}{ccccc}
\hline \multirow{2}{*}{ Treatments } & \multicolumn{2}{c}{ Spring Barley } & \multicolumn{2}{c}{ Faba Bean } \\
\cline { 2 - 5 } & Individuals & Biomass & Individuals & Biomass \\
\hline \multicolumn{5}{c}{ cropping system } \\
\hline CR * & $15.3 \pm 1.90$ & $7.4 \pm 0.94$ & $8.0 \mathrm{~b} * * \pm 2.07$ & $4.3 \mathrm{~b} \pm 1.28$ \\
CC & $14.7 \pm 3.37$ & $5.9 \pm 2.14$ & $13.3 \mathrm{a} \pm 3.21$ & $9.0 \mathrm{a} \pm 2.07$ \\
\hline \multicolumn{5}{c}{ plant protection } \\
HF- & $14.0 \pm 2.47$ & $5.9 \pm 1.52$ & $15.3 \mathrm{a} \pm 2.81$ & $9.4 \mathrm{a} \pm 2.19$ \\
HF+ & $16.0 \pm 2.91$ & $7.5 \pm 1.77$ & $6.0 \mathrm{~b} \pm 0.89$ & $4.0 \mathrm{~b} \pm 0.67$ \\
\hline CR-HF- & $18.7 \pm 1.33$ & $8.9 \pm 1.04$ & $10.7 \mathrm{~b} \pm 3.52$ & $5.5 \mathrm{~b} \pm 2.42$ \\
CR-HF+ & $12.0 \pm 6.92$ & $6.0 \pm 1.08$ & $5.3 \mathrm{~b} \pm 1.33$ & $3.0 \mathrm{~b} \pm 0.81$ \\
CC-HF- & $9.3 \pm 2.67$ & $2.8 \pm 1.06$ & $20.0 \mathrm{a} \pm 2.30$ & $13.2 \mathrm{a} \pm 1.83$ \\
CC-HF+ & $20.0 \pm 4.61$ & $9.1 \pm 3.46$ & $6.7 \mathrm{~b} \pm 1.33$ & $4.9 \mathrm{~b} \pm 0.85$ \\
\hline
\end{tabular}

* $\mathrm{CR}$ - crop rotation, $\mathrm{CC}$-continuous cropping, $\mathrm{HF}-$-no plant protection, $\mathrm{HF}+$-herbicide + fungicide; ${ }^{* *}$ values with different letters vary significantly (Duncan's test, $p<0.05$ ), no letters—no significant differences, $x \pm$ sem-mean \pm standard error of mean.

\subsection{Relationship Between Earthworm Abundance and Post-Harvest Residues, SOM, and Soil pH}

In spring barley fields, no relationship between earthworm abundance and post-harvest residues, SOM or soil $\mathrm{pH}$ was observed (Table 6). A strong positive association of SOM and earthworm abundance was noted in faba bean fields This suggests that organic matter left in the field by a legume, characterized by high protein content may be beneficial for earthworm populations. The above is in the line with Kladivko [82], where a higher density of earthworms in continuous soybean than in continuous corn was reported. The association between soil organic matter content and the presence of the earthworms was also observed in other findings [83,84]. Soil pH and dry mass of post-harvest residues were not significantly correlated with earthworm density or biomass. 
Table 6. The correlation coefficient ( $\mathrm{r}$ ) between density and biomass of earthworms with SOM, pH, and post-harvest residues of spring barley and faba bean fields.

\begin{tabular}{ccccc}
\hline \multirow{2}{*}{ Features } & \multicolumn{2}{c}{ Spring Barley } & \multicolumn{2}{c}{ Faba Bean } \\
\cline { 2 - 5 } & \multicolumn{4}{c}{ Earthworms } \\
\cline { 2 - 5 } & Individuals & Biomass & Individuals & Biomass \\
\hline residues & 0.095 & 0.030 & -0.116 & 0.057 \\
SOM & 0.192 & 0.105 & $0.730^{*}$ & $0.713^{*}$ \\
pH & 0.120 & 0.013 & -0.228 & -0.386 \\
\hline
\end{tabular}

\section{Conclusions}

In the current study post-harvest residues were unaffected by cropping system, but HF+ compared to HF- increased spring barely shoots residues and total post-harvest biomass and decreased weed post-harvest biomass. Experimental factors did not differentiate SOM in spring barley fields. CC, in relation to $\mathrm{CR}$, increased soil $\mathrm{pH}$ whereas $\mathrm{HF}+$ decreased it in comparison with $\mathrm{HF}-$. In spring barley fields, two earthworm species were found: Aporrectodea caliginosa (Sav.) and Aporrectodea rosea (Sav.). $\mathrm{CC}$ and HF+ did not affect earthworm density or biomass in relation to CR and HF-. No correlation between earthworm abundance and post-harvest residues, SOM, or soil $\mathrm{pH}$ was noted.

In faba bean fields above-ground post-harvest residue biomass was increased by CC in relation to CR. In turn, HF+ compared with HF- increased total and faba bean shoots and roots post-harvest biomass but decreased weeds post-harvest biomass. In faba bean fields, SOM stayed at the same level regardless of experimental factors. Lower $\mathrm{pH}$ values were noted under $\mathrm{CC}$ than $\mathrm{CR}$ treatment, whereas HF+ did not affect it. Aporrectodea caliginosa (Sav.) and Lumbricus terrestris (L.) were recorded in faba bean fields. CC increased earthworm density and biomass in comparison with $\mathrm{CR}$ whereas $\mathrm{HF}+$ decreased these features in relation to HF-. Positive correlations between earthworm density and biomass and SOM content were noted in faba bean fields.

Author Contributions: Conceptualization, K.T., M.J., and M.K.K.; methodology, K.T., M.J., and M.K.K.; validation, M.K.K. and P.M.; investigation, K.T. and P.M.; formal analysis, K.T., M.J., and P.M.; data curation, K.T. and P.M.; visualization, K.T., M.J., and M.K.K.; writing—original draft preparation, K.T.; writing—review and editing, M.J. and M.K.K.; funding acquisition, K.T. All authors have read and agreed to the published version of the manuscript.

Funding: This research was financially supported by the Minister of Science and Higher Education within the framework of the program entitled "Regional Initiative of Excellence" for the years 2019-2022, Project No. 010/RID/2018/19, amount of funding 12.000.000 PLN.

Conflicts of Interest: The authors declare no conflict of interest.

\section{References}

1. $\quad$ Blouin, M.; Hodson, M.E.; Delgado, E.A.; Baker, G.; Brussaard, L.; Butt, K.R.; Dai, J.; Dendooven, L.; Peres, G.; Tondoh, J.E.; et al. A review of earthworm impact on soil function and ecosystem services. Eur. J. Soil Sci. 2013, 64, 161-182. [CrossRef]

2. Bottinelli, N.; Henry-des-Tureaux, T.; Hallaire, V.; Mathieu, J.; Benard, Y.; Duc Tran, T.; Jouquet, P. Earthworms accelerate soil porosity turnover under watering conditions. Geoderma 2010, 156, 43-47. [CrossRef]

3. Pelosi, C.; Barot, S.; Capowiez, Y.; Hedde, M.; Vandenbulcke, F. Pesticides and earthworms. A review. Agron. Sustain. Dev. 2014, 34, 199-228. [CrossRef]

4. Jouquet, P.; Podwojewski, P.; Bottinelli, N.; Mathieu, J.; Ricoy, M.; Orange, D.; Tran, T.D.; Valentin, C. Above-ground earthworm casts affect water runoff and soil erosion in Northern Vietnam. Catena 2008, 74, 13-21. [CrossRef]

5. Winding, A.; Rønn, R.; Hendriksen, N.B. Bacteria and protozoa in soil microhabitats as affected by earthworms. Biol. Fertil. Soils 1997, 24, 133-140. [CrossRef]

6. Scheu, S.; Schlitt, N.; Tiunov, A.V.; Newington, J.E.; Jones, T.H. Effects of the presence and community composition of earthworms on microbial community functioning. Oecologia 2002, 133, 254-260. [CrossRef] 
7. Jouquet, P.; Bottinelli, N.; Podwojewski, P.; Hallaire, V.; Tran Duc, T. Chemical and physical properties of earthworm casts as compared to bulk soil under a range of different land-use systems in Vietnam. Geoderma 2008, 146, 231-238. [CrossRef]

8. Vos, H.M.J.; Koopmans, G.F.; Beezemer, L.; de Goede, R.G.M.; Hiemstra, T.; van Groenigen, J.W. Large variations in readily-available phosphorus in casts of eight earthworm species are linked to cast properties. Soil Biol. Biochem. 2019, 138, 107583. [CrossRef]

9. Eriksen-Hamel, N.S.; Whalen, J.K. Impacts of earthworms on soil nutrients and plant growth in soybean and maize agroecosystems. Agric. Ecosyst. Environ. 2007, 120, 442-448. [CrossRef]

10. Fonte, S.J.; Kong, A.Y.Y.; van Kessel, C.; Hendrix, P.F.; Six, J. Influence of earthworm activity on aggregate-associated carbon and nitrogen dynamics differs with agroecosystem management. Soil Biol. Biochem. 2007, 39, 1014-1022. [CrossRef]

11. Sruthi, S.N.; Ramasamy, E.V. Enrichment of soil organic carbon by native earthworms in a patch of tropical soil, Kerala, India: First report. Sci. Rep. 2018, 8, 5784. [CrossRef]

12. Krishnamoorthy, R.V.; Vajranabhaiah, S.N. Biological activity of earthworm casts: An assessment of plant growth promotor levels in the casts. Proc. Anim. Sci. 1986, 95, 341-351. [CrossRef]

13. Muscolo, A.; Bovalo, F.; Gionfriddo, F.; Nardi, S. Earthworm humic matter produces auxin-like effects on Daucus carota cell growth and nitrate metabolism. Soil Biol. Biochem. 1999, 31, 1303-1311. [CrossRef]

14. Blouin, M.; Zuily-Fodil, Y.; Pham-Thi, A.T.; Laffray, D.; Reversat, G.; Pando, A.; Tondoh, J.; Lavelle, P. Belowground organism activities affect plant aboveground phenotype, inducing plant tolerance to parasites. Ecol. Lett. 2005, 8, 202-208. [CrossRef]

15. Boyer, J.; Reversat, G.; Lavelle, P.; Chabanne, A. Interactions between earthworms and plant-parasitic nematodes. Eur. J. Soil Biol. 2013, 59, 43-47. [CrossRef]

16. Stephens, P.M.; Davoren, C.W.; Doube, B.M.; Ryder, M.H. Ability of the lumbricid earthworms Aporrectodea rosea and Aporrectodea trapezoides to reduce the severity of take-all under greenhouse and field conditions. Soil Biol. Biochem. 1994, 26, 1291-1297. [CrossRef]

17. Van Groenigen, J.W.; Lubbers, I.M.; Vos, H.M.J.; Brown, G.G.; De Deyn, G.B.; Van Groenigen, K.J. Earthworms increase plant production: A meta-analysis. Sci. Rep. 2014, 4, 6365. [CrossRef] [PubMed]

18. Scheu, S. Effects of earthworms on plant growth: Patterns and perspectives. Pedobiologia 2003, 47, 846-856. [CrossRef]

19. Baldivieso-Freitas, P.; Blanco-Moreno, J.M.; Gutiérrez-López, M.; Peigné, J.; Pérez-Ferrer, A.; Trigo-Aza, D.; Sans, F.X. Earthworm abundance response to conservation agriculture practices in organic arable farming under Mediterranean climate. Pedobiologia 2018, 66, 58-64. [CrossRef]

20. Falco, L.B.; Sandler, R.; Momo, F.; Di Ciocco, C.; Saravia, L.; Coviella, C. Earthworm assemblages in different intensity of agricultural uses and their relation to edaphic variables. Peer] 2015, 3, e979. [CrossRef]

21. Gerard, B.M.; Hay, R.K.M. The effect on earthworms of ploughing, tined cultivation, direct drilling and nitrogen in a barley monoculture system. J. Agric. Sci. 1979, 93, 147-155. [CrossRef]

22. Curry, J.P.; Byrne, D.; Schmidt, O. Intensive cultivation can drastically reduce earthworm populations in arable land. Eur. J. Soil Biol. 2002, 38, 127-130. [CrossRef]

23. Emmerling, C. Response of earthworm communities to different types of soil tillage. Appl. Soil Ecol. 2001, 17, 91-96. [CrossRef]

24. Capowiez, Y.; Cadoux, S.; Bouchant, P.; Ruy, S.; Roger-Estrade, J.; Richard, G.; Boizard, H. The effect of tillage type and cropping system on earthworm communities, macroporosity and water infiltration. Soil Tillage Res. 2009, 105, 209-216. [CrossRef]

25. Metzke, M.; Potthoff, M.; Quintern, M.; Heß, J.; Joergensen, R.G. Effect of reduced tillage systems on earthworm communities in a 6-year organic rotation. Eur. J. Soil Biol. 2007, 43, 209-215. [CrossRef]

26. Bohlen, P.J.; Edwards, C.A.; Zhang, Q.; Parmelee, R.W.; Allen, M. Indirect effects of earthworms on microbial assimilation of labile carbon. Appl. Soil Ecol. 2002, 20, 255-261. [CrossRef]

27. Parmelee, R.W.; Beare, M.H.; Cheng, W.; Hendrix, P.F.; Rider, S.J.; Crossley, D.A.; Coleman, D.C. Earthworms and enchytraeids in conventional and no-tillage agroecosystems: A biocide approach to assess their role in organic matter breakdown. Biol. Fertil. Soils 1990, 10, 1-10. [CrossRef]

28. Edwards, C.A.; Lofty, J.R. Nitrogenous fertilizers and earthworm populations in agricultural soils. Soil Biol. Biochem. 1982, 14, 515-521. [CrossRef] 
29. Eriksen-Hamel, N.S.; Speratti, A.B.; Whalen, J.K.; Légère, A.; Madramootoo, C.A. Earthworm populations and growth rates related to long-term crop residue and tillage management. Soil Tillage Res. 2009, 104, 311-316. [CrossRef]

30. Edwards, C.A.; Bohlen, P.J. The effects of toxic chemicals on earthworms. Rev. Environ. Contam. Toxicol. 1992, 125, 23-100.

31. Bustos-Obregón, E.; Goicochea, R.I. Pesticide soil contamination mainly affects earthworm male reproductive parameters. Asian J. Androl. 2002, 4, 195-199.

32. Yasmin, S.; D'Souza, D. Effects of pesticides on the growth and reproduction of earthworm: A review. Appl. Environ. Soil Sci. 2010, 2010, 678360. [CrossRef]

33. Ndubuisi, S.O.; Obiezue, R.N.; Amarachi, O.; Onuoha, E. Toxicity and histopathological effect of atrazine (Herbicide) on the earthworm Nsukkadrilus mbae under laboratory conditions. Anim. Res. Int. 2010, 7, 1287-1293.

34. Xiao, N.; Jing, B.; Ge, F.; Liu, X. The fate of herbicide acetochlor and its toxicity to Eisenia fetida under laboratory conditions. Chemosphere 2006, 62, 1366-1373. [CrossRef] [PubMed]

35. Correia, F.V.; Moreira, J.C. Effects of glyphosate and 2,4-D on earthworms (Eisenia foetida) in laboratory tests. Bull. Environ. Contam. Toxicol. 2010, 85, 264-268. [CrossRef] [PubMed]

36. Muthukaruppan, G.; Janardhanan, S.; Vijayalakshmi, G.S. Sublethal toxicity of the herbicide butachlor on the earthworm Perionyx sansibaricus and its histological changes. J. Soils Sediments 2005, 5, 82-86. [CrossRef]

37. Gobi, M.; Gunasekaran, P. Effect of butachlor herbicide on earthworm Eisenia fetida-Its histological perspicuity. Appl. Environ. Soil Sci. 2010, 2010,1-4. [CrossRef]

38. Singh, V.; Singh, K. Toxic Effect of herbicide 2,4-D on the earthworm Eutyphoeus waltoni Michaelsen. Environ. Process. 2015, 2, 251-260. [CrossRef]

39. Givaudan, N.; Wiegand, C.; Le Bot, B.; Renault, D.; Pallois, F.; Llopis, S.; Binet, F. Acclimation of earthworms to chemicals in anthropogenic landscapes, physiological mechanisms and soil ecological implications. Soil Biol. Biochem. 2014, 73, 49-58. [CrossRef]

40. Duc, G. Faba bean (Vicia faba L.). Field Crop. Res. 1997, 53, 99-109. [CrossRef]

41. Kasprzak, K. Skaposzczety Glebowe, III: Rodzina; dżdżownice (Lumbricidae); MiIZ PAN: Warszawa, Poland, 1986.

42. Zhang, H.; Wang., J.J. Soil pH Changes During Legume Growth and Application of Plant Material; Southern Extension and Research Activity Information Exchange Group 6; University of Georgia: Athens, Greece, 2014.

43. Lv, J.; Dong, Y.; Dong, K.; Zhao, Q.; Yang, Z.; Chen, L. Intercropping with wheat suppressed Fusarium wilt in faba bean and modulated the composition of root exudates. Plant Soil. 2020, 448, 153-164. [CrossRef]

44. Rychcik, B.; Zawiślak, K. Effect of crop rotation and monoculture on faba bean phytosanitary and production. Pam. Put. 2002, 130, 623-659.

45. Kotecki, A. The influence of row spacing and quantity of seeds sown on the development and yielding of Tibo cultivar field bean with terminal inflorescence Zesz. Nauk. AR We Wrocławiu. 1994, 238, 133-143.

46. Rychcik, B. Effect of herbicide and crop sequence on weed infestation of field bean. Prog. Plant Prot. 2004, 44, 1058-1060.

47. Adamiak, E.; Adamiak, J.; Stępień, A. Wpływ następstwa roślin i stosowania herbicydów na zachwaszczenie jęczmienia jarego. Ann. Univ. Mariae Curie-Skłodowska 2000, 55, 9-15.

48. Rychcik, B.; Adamiak, J.; Wójciak, H. Dynamics of the soil organic matter in crop rotation and long-term monoculture. Plant Soil Environ. 2006, 52, 12-20.

49. Yang, X.M.; Kay, B.D. Rotation and tillage effects on soil organic carbon sequestration in a typic Hapludalf in southern Ontario. Soil Tillage Res. 2001, 59, 107-114. [CrossRef]

50. Campbell, C.A.; Biederbeck, V.O.; Zentner, R.P.; Lafond, G.P. Effect of crop rotations and cultural practices on soil organic matter, microbial biomass and respiration in a thin Black Chernozem. Can. J. Soil Sci. 1991, 71, 363-376. [CrossRef]

51. Blair, N.; Crocker, G.J. Crop rotation effects on soil carbon and physical fertility of two Australian soils. Aust. J. Soil Res. 2000, 38, 71-84. [CrossRef]

52. Hickman, M.V. Long-term tillage and crop rotation effects on soil chemical and mineral properties. J. Plant Nutr. 2002, 25, 1457-1470. [CrossRef]

53. Van Beusichem, M.L. Nutrient absorption by pea plants during dinitrogen fixation. I. Comparison with nitrate nutrition. Neth. J. Agric. Sci. 1981, 29, 259-272. 
54. Bolan, N.S.; Hedley, M.J.; White, R.E. Processes of soil acidification during nitrogen cycling with emphasis on legume based pastures. Plant Soil 1991, 134, 53-63. [CrossRef]

55. Tang, C.; Unkovich, M.J.; Bowden, J.W. Factors affecting soil acidification under legumes. III. Acid production by N2-fixing legumes as influenced by nitrate supply. New Phytol. 1999, 143, 513-521. [CrossRef]

56. Lee, B. Farming brings acid soils. Rural Res. 1980, 106, 4-9.

57. Williams, C.H. Soil acidification under clover pasture. Aust. J. Exp. Agric. 1980, 20, 561-567. [CrossRef]

58. Valchovski, H. Effect of erosion on biodiversity of earthworms (Lumbricidae) in agroecosystems of Suhodol (Sofia province). Semin. Ecol. 2012, 182-189.

59. Fragoso, C.; Brown, G.G.; Patrón, J.C.; Blanchart, E.; Lavelle, P.; Pashanasi, B.; Senapati, B.; Kumar, T. Agricultural intensification, soil biodiversity and agroecosystem function in the tropics: The role of earthworms. Appl. Soil Ecol. 1997, 6, 17-35. [CrossRef]

60. Paoletti, M.G. The role of earthworms for assessment of sustainability and as bioindicators. Agric. Ecosyst. Environ. 1999, 74, 137-155. [CrossRef]

61. Curry, J.P.; Doherty, P.; Purvis, G.; Schmidt, O. Relationships between earthworm populations and management intensity in cattle-grazed pastures in Ireland. Appl. Soil Ecol. 2008, 39, 58-64. [CrossRef]

62. Edwards, C.A. Earthworm ecology in cultivated soils. In Earthworm Ecology; Springer: Dordrecht, The Netherlands, 1983; pp. 123-137.

63. Bart, S.; Amossé, J.; Lowe, C.N.; Mougin, C.; Péry, A.R.R.; Pelosi, C. Aporrectodea caliginosa, a relevant earthworm species for a posteriori pesticide risk assessment: Current knowledge and recommendations for culture and experimental design. Environ. Sci. Pollut. Res. 2018, 25, 33867-33881. [CrossRef]

64. Feledyn-Szewczyk, B.; Radzikowski, P.; Stalenga, J.; Matyka, M. Comparison of the effect of perennial energy crops and arable crops on earthworm populations. Agronomy 2019, 9, 675. [CrossRef]

65. Holmstrup, M.; Overgaard, J. Freeze tolerance in Aporrectodea caliginosa and other earthworms from Finland. Cryobiology 2007, 55, 80-86. [CrossRef] [PubMed]

66. Zorn, M.I.; Van Gestel, C.A.M.; Morrien, E.; Wagenaar, M.; Eijsackers, H. Flooding responses of three earthworm species, Allolobophora chlorotica, Aporrectodea caliginosa and Lumbricus rubellus, in a laboratory-controlled environment. Soil Biol. Biochem. 2008, 40, 587-593. [CrossRef]

67. Nuutinen, V. Earthworm community response to tillage and residue management on different soil types in southern Finland. Soil Tillage Res. 1992, 23, 221-239. [CrossRef]

68. Holter, P. Effect of earthworms on the disappearance rate of cattle droppings. In Earthworm Ecology; Springer: Dordrecht, The Netherlands, 1983; pp. 49-57.

69. Ivask, M.; Kuu, A.; Sizov, E. Abundance of earthworm species in Estonian arable soils. Eur. J. Soil Biol. 2007, 43, 39-42. [CrossRef]

70. Pfiffner, L.; Luka, H. Earthworm populations in two low-input cereal farming systems. Appl. Soil Ecol. 2007, 37, 184-191. [CrossRef]

71. Jastrzebska, M.; Kostrzewska, M.K.; Makowski, P.; Treder, K.; Marks, M. Effects of ash and bone phosphorus biofertilizers on Bacillus megaterium counts and select biological and physical soil properties. Polish J. Environ. Stud. 2015, 24, 1603-1609. [CrossRef]

72. Orzech, K.; Załuski, D. Chemical properties of soil and occurrence of earthworms in soil in response to soil compaction and different soil tillage in cereals. J. Elem. 2020, 25, 153-168. [CrossRef]

73. Jastrzębska, M.; Kostrzewska, M.; Makowski, P.; Treder, K.; Jastrzęskki, W. Granulated phosphorus fertilizer made of ash from biomass combustion and bones with addition of Bacillus megaterium in the field assessment. Part 3. Impact on selected properties of soil environment of winter wheat. Przem. Chem. 2017, 96, 2180-2183.

74. Orzech, K.; Załuski, D. Effect of soil compaction and different soil tillage systems on chemical properties of soil and presence of earthworms in winter oilseed rape fields. J. Elem. 2020, 25, 413-429.

75. Badawy, M.E.I.; Kenawy, A.; El-Aswad, A.F. Toxicity assessment of buprofezin, lufenuron, and triflumuron to the earthworm Aporrectodea caliginosa. Int. J. Zool. 2013, 2013, 174523. [CrossRef]

76. Mosleh, Y.Y.; Ismail, S.M.M.; Ahmed, M.T.; Ahmed, Y.M. Comparative toxicity and biochemical responses of certain pesticides to the mature earthworm Aporrectodea caliginosa under laboratory conditions. Environ. Toxicol. 2003, 18, 338-346. [CrossRef] [PubMed]

77. Gaupp-Berghausen, M.; Hofer, M.; Rewald, B.; Zaller, J.G. Glyphosate-based herbicides reduce the activity and reproduction of earthworms and lead to increased soil nutrient concentrations. Sci. Rep. 2015, 5, 12886. [CrossRef] 
78. Dittbrenner, N.; Triebskorn, R.; Moser, I.; Capowiez, Y. Physiological and behavioural effects of imidacloprid on two ecologically relevant earthworm species (Lumbricus terrestris and Aporrectodea caliginosa). Ecotoxicology 2010, 19, 1567-1573. [CrossRef] [PubMed]

79. Capowiez, Y.; Rault, M.; Costagliola, G.; Mazzia, C. Lethal and sublethal effects of imidacloprid on two earthworm species (Aporrectodea nocturna and Allolobophora icterica). Biol. Fertil. Soils 2005, 41, 135-143. [CrossRef]

80. Hodge, S.; Webster, K.M.; Booth, L.; Hepplethwaite, V.; O’Halloran, K. Non-avoidance of organophosphate insecticides by the earthworm Aporrectodea caliginosa (Lumbricidae). Soil Biol. Biochem. 2000, 32, 425-428. [CrossRef]

81. López-Hernández, D. Earthworm populations in savannas of the Orinoco basin. A review of studies in long-term agricultural-managed and protected ecosystems. Agriculture 2012, 2, 87-108. [CrossRef]

82. Kladivko, E.J. Earthworms and Crop Management.; Purdue University: West Lafayette, IN, USA, 1993.

83. Fonte, S.J.; Winsome, T.; Six, J. Earthworm populations in relation to soil organic matter dynamics and management in California tomato cropping systems. Appl. Soil Ecol. 2009, 41, 206-214. [CrossRef]

84. Haynes, R.J.; Dominy, C.S.; Graham, M.H. Effect of agricultural land use on soil organic matter status and the composition of earthworm communities in Kwazulu-Natal, South Africa. Agric. Ecosyst. Environ. 2003, 95, 453-464. [CrossRef]

(C) 2020 by the authors. Licensee MDPI, Basel, Switzerland. This article is an open access article distributed under the terms and conditions of the Creative Commons Attribution (CC BY) license (http://creativecommons.org/licenses/by/4.0/). 